\title{
Pengelolaan Konflik Sumber D aya Alam Terbarukan di Perbatasan dalam Pendekatan Ekologi Politik
}

\author{
Herdis Herdiansyah \\ School of Environmental Science \\ Universitas Indonesia \\ J. Salemba Raya No.4 J akarta Pusat 10430 \\ herdis@ui.ac.id \\ Diserahkan: 4 September 2018; diterima: 21 Desember 2018
}

\begin{abstract}
A bstract
The different interest among actors (government, society, and corporations) has become one of the causes of conflict in natural resources managements. In border areas, conflict arises because of abundant land availability and diverse natural resources that have a potency to be utilized for a variety of purposes. M eanw hile, the political ecology approach sees these differences of interest arise from economic, social, and political motives or it can be driven by an environmental control. Political ecology approach can help to illustrate the phenomenon, by linking the environmental condition to the process of the political economy. Political ecology becomes operational when it acts as an environmental policy and spur the government to act collaboratively with privates and communities. In addition, natural resources management must include the right and responsibilities in the future. To assuring the conflict of natural resources management at the border will not escalate, the approach of the security law need to be implemented at the border besides the welfare approach.

Keywords: political ecology, conflict, natural resources management, border area.
\end{abstract}

\begin{abstract}
Abstrak
Perbedaan kepentingan antaraktor (pemerintah, masyarakat, dan korporasi) menjadi salah satu penyebab konflik terkait pengelolaan sumber daya alam. Di wilayah perbatasan, konflik muncul karena lahan dan keanekaragaman sumber daya alam yang berpotensi untuk dimanfaatkan tersedia secara melimpah. Dalam pendekatan ekologi politik, perbedaan kepentingan ini dilatarbelakangi oleh motif ekonomi, sosial politik, dan penguasaan lingkungan. Pendekatan ekologi politik dapat membantu menggambarkan fenomena dengan mengaitkan kondisi lingkungan dan proses ekonomi politik. Ekologi politik menjadi operasional karena dapat menjadi politik kebijakan lingkungan, yaitu ketika pemerintah mampu bekerja sama secara integratif dengan swasta dan masyarakat. Manajemen sumber daya alam di masa depan harus secara jelas melibatkan hak pembagian sumber daya alam dan tanggung jawab pengelolaan di dalamnya. Untuk mencegah konflik pengelolaan sumber daya alam di perbatasan tidak berkembang pada skala lebih besar, maka pendekatan hukum keamanan perlu didukung dengan pendekatan kesejahteraan.
\end{abstract}

Kata kunci: ekologi politik, konflik, pengelolaan sumber daya alam, wilayah perbatasan.

\section{PENDAHULUAN}

Sawit merupakan sumber daya alam terbarukan yang kini gencar dikembangkan di daerah perbatasan. Produk turunan sawit dalam bentuk minyak merupakan komoditas perkebunan yang dibutuhkan berbagai industri, mulai dari makanan, kosmetik, kebutuhan rumah tangga, kesehatan, pakan ternak, hingga bahan kimia. Malaysia dan Indonesia adalah penghasil minyak kelapa sawit terbesar di dunia, dengan kontribusi 85\% dari keluaran global (Erman, 2018), di mana 53\% nya merupakan capaian Indonesia dan 32\% Malaysia. Kedua negara ini juga merupakan pengekspor terbesar dunia, mencapai 93\%, dengan persentase ekspor Indonesia 55\% dan Malaysia 38\% dari total ekspor minyak kelapa sawit global. M inyak kelapa sawit dianggap sebagai sektor ekonomi strategis di kedua negara karena secara signifikan berkontribusi terhadap produk domestik bruto (PDB), pendapatan ekspor, ketersediaan lapangan kerja, 
dan pembangunan sosial ekonomi pedesaan (Nesadurai, 2018).

M eskipun dari tahun 2007 Indonesia memegang posisi produsen minyak kelapa sawit pertama dunia, namun sebagian besar perusahaan kelapa sawit yang beroperasi di Indonesia masih didominasi oleh perusahaan asal M alaysia. Hal ini muncul akibat adanya kebutuhan lahan dan tenaga kerja murah yang didorong kebijakan liberalisasi investasi di Indonesia saat krisis moneter 1997 (N esadurai, 2018). Beberapa perusahaan dari M alaysia memanfaatkan situasi tersebut dengan mengekspansi perkebunan kelapa sawit yang merupakan sumber daya alam di wilayah Indonesia terutama di area-area perbatasan Indonesia-M alaysia.

Fluktuasi permintaan minyak kelapa sawit kerap terjadi, namun diperkirakan pada tahun 2050 permintaan atas minyak goreng global meningkat hingga 240 juta ton atau hampir dua kali lipat dari kebutuhan tahun 2008, sedangkan konsumsi minyak nabati dunia pada tahun 2008-2012 sudah mencapai 132 juta ton. Jika dikonversi terhadap ketersediaan lahan, maka dibutuhkan penambahan areal perkebunan sawit sebanyak 12 juta hektar (H andadhari, 2010). Pada industri sawit dengan luas 7,5 juta hektar dengan kapasitas produksi minyak mentah sebanyak 19 juta ton, dapat menyumbang sekitar 14 miliar dollar AS per tahun bagi keuangan negara. Pada satu sisi, permintaan sawit dihadapkan pada keterbatasan lahan, sehingga mengakibatkan sebuah negara semakin ekspansif membuka dan mencari lahan-lahan baru. Keterbatasan lahan perkebunan dan keinginan Malaysia menjadi penghasil utama produk turunan sawit, membuat $M$ alaysia gencar melakukan ekspansi dan membuka lahan-lahan sawit baru di Indonesia. Alasan pemilihan lahan baru tersebut mempertimbangkan jenis tanah podsol di Indonesia (dan juga Malaysia) dengan curah hujan 1.000-2.500 milimeter per tahun, yang membuat lahan tersebut berpotensi sangat produktif untuk pertumbuhan kelapa sawit.

D alam G overnment Plans W orld's L argest Palm 0 il Plantations berkaitan dengan rencana pembangunan areal 1,8 juta hektar sawit di daerah perbatasan, pemerintah menyebutkan beberapa elemen dasar pengembangan industri sawit sepanjang perbatasan Kalimantan, Sabah, dan Sarawak. Elemen dasar yang juga tujuan utama proyek tersebut adalah memperpendek perbedaan kemakmuran antaralndonesia (Kalimantan) dan Malaysia, menurunkan angka insiden illegal logging sepanjang perbatasan, menciptakan lapangan kerja dan memproduksi bio energi untuk konsumsi dalam negeri dan komoditas ekspor. Di sisi lain, proyek transnasional yang melibatkan multi-stakeholder ini dapat berdampak pada keamanan nasional, terutama potensi konflik pengelolaan sumber daya alam.

Sistem politik internasional dalam pengelolaan sumber daya alam menggambarkan kerawanan terhadap konflik yang terjadi karena setiap negara berpacu pada kelangkaan dan keterbatasan sumber daya alam. Sistem politik internasional terkait sumber daya alam terdiri atas kelas aktor dan negara yang mengukur kemajuan berdasarkan eksploitasi aktor di negara-negara lain (Weinstein, 2005). Studi Martin (2005) tentang konflik sumber daya alam di A frika secara radikal mengatakan bahwa dominasi sumber daya oleh korporasi asing merupakan kesengajaan. Martin (2005) mengatakan kesengajaan itu merupakan warisan dari upaya untuk mengurangi penduduk Afrika dalam rangka memenuhi selera negara lain (Barat) terhadap produk yang dibuat dari sumber daya alam A frika.

Ekspansi perkebunan kelapa sawit di wilayah perbatasan memunculkan dua sisi bertentangan. Di satu sisi, pengembangan ini telah menciptakan kesempatan kerja sekaligus menurunkan minat tenaga kerja Indonesia untuk bermigrasi ke Malaysia. Sehingga semakin banyak tenaga kerja yang terserap di sektor perkebunan kelapa sawit Indonesia (N gadi \& N overia, 2018). Namun, di sisi lain, perkebunan kelapa sawit yang melakukan ekspansi adalah milik asing. Sebagai contoh, penelitian yang dilakukan oleh Potter (2008) menunjukan bagaimana ancaman ekspansi perkebunan kelapa sawit milik asing sejak era liberalisasi investasi O rde Baru terhadap ketahanan masyarakat D ayak dan peningkatan konflik antarpemangku kepentingan.

W ilayah perbatasan mempunyai peran penting dalam kedaulatan suatu negara. Terjadinya konflik di wilayah perbatasan dapat menyebabkan masalah pada hubungan Indonesia-Malaysia. O leh karena itu, dibutuhkan suatu pengelolaan konflik agar suatu masalah tidak mengglobal dan mengganggu hubungan yang telah terjalin antara dua negara terlibat. Dalam struktur hubungan internasional, konstruksi harmoni pengelolaan sumber daya alam 
terbarukan di perbatasan diperlukan untuk menciptakan hubungan saling menghargai dan pro terhadap perlindungan lingkungan.

\section{KERANGKA PEMIKIRAN}

KONFLIK SUMBER DAYA ALAM DAN PENGELOLAAN PERBATASAN

Konflik sumber daya terjadi tidak lepas dari pendekatan M althusian yang sejak awal menunjukkan bahwa pertumbuhan populasi manusia akan melebihi ketersediaan sumber daya al am ( $\mathrm{H}$ ardin, 1968). M asalah pertumbuhan jumlah penduduk terutama di negara-negara kategori dunia ketiga menjadi fokus masalah perekonomian dunia (Smith et al., 1998). Peningkatan jumlah penduduk menyebabkan berbagai dampak negatif terhadap sosial seperti kompetisi berlebih atas suatu sumber daya dan pada akhirnya menimbulkan konflik. Bongaarts (1996) dalam G reen (2002) menyebutkan bahwa peningkatan populasi dan kepadatan manusia mengarah pada kelangkaan tanah dan bahan pangan. Sementara kelangkaan bahan pangan menyebabkan degradasi lingkungan lebih lanjut seperti deforestasi, salinisasi tanah, polusi udara, dan kepunahan keanekaragaman hayati.

Perpindahan penduduk ke daerah yang dianggap lebih menjanjikan dengan ketersediaan faktor penopang kehidupan dipandang mampu mengatasi masalah. Namun, secara sosial membawa berbagai dampak yang tidak menguntungkan, salah satunya gesekan antara penduduk asli dengan pendatang yang memiliki budaya serta prinsip hidup berbeda, penduduk asli merasa kedatangan imigran akan mengancam keberlangsungan hidup dan menodai nilai-nilai yang selama ini mereka anut. A kan tetapi bagi para pendatang, daerah yang mereka tuju adalah dunia baru yang harus ditaklukan. Pada akhirnya konflik sosial pun tidak bisa dihindari. Green (2002) mengurai cara kemajuan industri memecah masyarakat menjadi kelaskelas dalam strata sosial di dalamnya, di mana sering terjadi gesekan yang pada akhirnya menimbulkan konflik di antara kelas-kelas tersebut.

Berbagai konflik internal terkait sumber daya alam yang terjadi di seluruh dunia sejak tahun 1945 bersifat lokal. Hingga pertengahan 1970, meningkatnya konflik telah menyebabkan semakin bertambahnya pembentukan negara-negara baru di dunia seiring dengan selesainya kolonialisme teritorial berupa agresi kewilayahan. Bahkan setelah itu, pertumbuhan konflik lingkungan berjalan lebih cepat dibanding proses perkembangan negara-negara baru (G ledittsch, 1998). Banyak di antara konflik ini terjadi pada negara-negara berkembang, terutama negara dengan tingkat degradasi lingkungan tinggi seperti Amerika Tengah dan negara-negara di A frika (H auge et al., 1998).

Konflik internal di dalam suatu negara memiliki dampak yang bersifat multi-skalar dan multi-sistem terhadap dunia alami. M isal nya penelitian yang dilakukan oleh $\mathrm{H}$ art dan M winyihali (2001) melihat konflik yang terjadi di Republik Demokratik Kongo (DRC) telah meningkatkan tekanan pada sistem alami atas ketersediaan sumber protein dan kebutuhan kalori sebagai dampak dari hilangnya keanekaragaman hayati.

M asalah lain yang ditemukan pada kasus DRC adalah marginalisasi atas strategi-strategi dan program-program konversi melalui peningkatan perburuan liar atas spesiesspesies terancam punah dan melalui penyebaran permodalan pemerintah untuk manajemen dan proteksi sumber daya alam. Lalu, seperti juga DRC, kasus konflik yang terjadi di Ethiopia memperlihatkan betapa sulitnya membangun dan merawat strategi-strategi konservasi, menjalankan manajemen sumber daya serta area-area yang diproteksi (Fisher, 2010).

Kanyamibwa (1998) meneliti masalah pasca konflik yang terjadi di R wanda dan menemukan bahwa kerusakan masih terus terjadi setelah konflik selesai, mencakup kerusakan alam liar dan habitatnya, polusi sungai dan sistem air bersih, marginalisasi taman-taman, area terlindungi, dan manajemen sumber daya, serta isolasi atas populasi-populasi dari berbagai macam spesies dikarenakan adanya konversi habitat yang mereka tempati (Fisher, 2010). Konflik sumber daya alam menjadi besar karena merupakan kepentingan/ hak bersama sehingga persinggungan pemanfaatan dan penggunaan tidak terhindarkan. D engan demikian, konflik yang muncul bukan hanya antarindividu, tetapi dengan korporasi, bahkan dengan negara. Di sinilah konflik pribadi berkembang menjadi konflik intrastate dan kemudian berkembang menjadi konflik global. Banyak peneliti memfokuskan diri untuk mencari jawaban atas fenomena yang berkembang di masa sekarang, 
yaitu bagaimana konflik internal dalam suatu negara bisa meluas menjadi konflik global. Tidak dapat dipungkiri bahwa setiap konflik internasional seringkali mengandung maksud menguasai sumber daya tertentu, termasuk konflikkonflik yang diselesaikan dengan bantuan militer. Sebagai contoh, Perang Vietnam yang oleh beberapa kalangan dianggap sebagai alasan AS untuk tetap dapat menikmati akses terhadap sumber daya timah, karet, dan beras ( $M$ andel, 1980). H ubungan antara faktor ekologi dan sosial adalah suatu keadaan yangsangat dinamis (M cN eill, 2001) yang dapat dipetakan dalam bagan berikut.

\section{Gambar 1. Sumber dan konsekuensi kelangkaan sumber daya alam yang dapat diperbaharui}

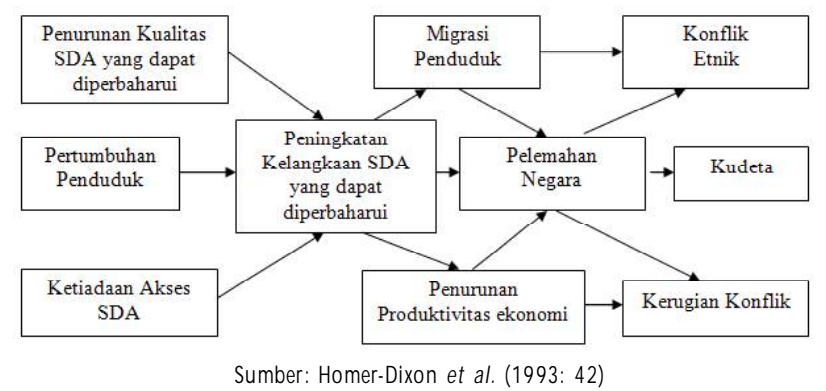

PENGELOLAAN SUM BER DAYA ALAM DI PERBATASAN DALAM PERSPEKTIF EKOLOGI POLITIK

Ekologi politik lahir sebagai pendekatan yang melihat masalah lingkungan sebagai masalah struktural dan material. Salah satu pendekatan strukturalis adalah pendekatan aktor yang diperkenalkan Bryant dan Beiley (2001) dalam Satria (2006) yang mengatakan bahwa konsep politicized environment membuat cara pandang lingkungan tidak lepas dari pengaruh ekonomi dan politik. Sehingga masalah lingkungan tidak akan pernah selesai dengan melihat ke arah teknis saja. Ekologi politik ini mengeksplorasi berbagai kepentingan yang muncul dalam pengelolaan kebijakan tentang lingkungan. Perbedaan kepentingan menjadikan tidak adanya satu pengertian yang tetap, karena masingmasing aktor didefinisikan berdasarkan kepentingannya. Pendekatan ekologi politik dapat membantu menggambarkan fenomena dengan mengaitkan kondisi lingkungan dengan proses ekonomi politik (Peet \& Watts, 1996).

Istilah ekologi politik diperkirakan baru digunakan pada era 70an dengan definisi beragam dan memberi penekanan berbeda pada cara pandang dan dengan mengaitkan pendekatan Iainnya. Ekologi politik merupakan bidang kajian yang mempelajari aspek-aspek sosial politik terhadap pengelolaan lingkungan. Inti pemaknaan dalam ekologi politik adalah bahwa perubahan lingkungan tidaklah bersifat netral, melainkan merupakan suatu bentuk politisasi lingkungan di mana melibatkan banyak aktor yang memiliki kepentingan terhadap lingkungan itu sendiri. $\mathrm{H}$ al ini dapat terjadi baik pada tingkat lokal, regional, maupun global.

Sebagai ranah studi, ekologi politik dikaitkan dengan tingkah laku pengguna sumber daya dalam pengaturan spesifik dengan politik, institusi, dan hubungan sosial yang merupakan pengaturan pada tingkah laku tersebut. Pada sisi lain, C ockburn dan Ridgeway (1979) menggambarkan ekologi politik sebagai tujuan terselubungyang dilakukan negara-negara industri untuk dapat mengeksploitasi lingkungan yang men gakibatkan adanya rakitan ilmu sosial politik, ekonomi, dan ekologi. Hal ini memunculkan sebuah pengertian ekologi politik, antara lain mempelajari sumber, kondisi, dan implikasi politik dari perubahan lingkungan hidup; menggambarkan kaitan dan hubungan yang terjalin antara masyarakat dan lingkungan hidupnya yang digambarkan melalui akses dan kontrol sumber daya alam dan memengaruhi keberadaannya di masa depan; dan merupakan kaitan erat ilmu ekologi dan ekonomi politik (H empel, 1996). Pendapat lain dikemukakan oleh Forsyth (2003) yang dikenal sebagai pakar ekologi politik menjelaskan bahwa pendekatan ekologi politik merupakan kelanjutan dari kajian ekologi budaya (cultural ecology).

\section{HASIL DAN PEMBAHASAN}

\section{KONFLIK SAWIT DI WILAYAH PERBATASAN}

Kawasan perbatasan Indonesia membentang dan melingkupi wilayah cukup luas. Perbatasan Indonesia terdiri dari perbatasan darat dan perbatasan laut. Di wilayah Kalimatan, Indonesia berbatasan langsung dengan M alaysia, Papua berbatasan langsung dengan Papua N ugini (PNG), dan Provinsi Nusa Tenggara Timur berbatasan langsung dengan Timor Leste. Sedangkan perbatasan laut Indonesia berbatasan dengan banyak negara seperti, M alaysia, Singapura, Thailand, Republik Palau, Australia, PNG (Papua Nugini), Timor Leste, Vietnam, dan India. 
Namun secara sosial ekonomi perbatasan darat wilayah tersebut tidak merata. Misalnya wilayah perbatasan Kalimantan dan M alaysia secara kasat mata lebih sejahtera dengan infrastruktur yang rapi dan tertata dibanding wilayah Papua dan Papua N ugini (M aharyudi, 2006).

Tinjauan pengelolaan daerah perbatasan bagi Indonesia adalah kajian yang terus berkembang seiring pergantian kekuasaan pusat; terutama setelah kejatuhan O rde Baru dan krisis ekonomi, wilayah perbatasan semakin terabaikan. M eskipun pada saat pemerintahan Suharto, paradigma pengelolaan perbatasan menjadi penyangga dan pelindung keamanan (Eilenberg \& Wadley, 2009). Pengabaian tidak hanya mencakup permasalahan ekonomi, pendidikan, dan infrastruktur, namun juga pengabaian perlindungan daerah rawan bencana lingkungan seperti kebakaran hutan, longsor, dan banjir. O leh karena itu, permasalahan kebakaran hutan akibat pembukaan lahan untuk pengembangan perkebuanan kelapa sawit masih belum ditangani secara sungguh-sungguh. Pengabaian ini membawa ancaman serius bagi bencana ekologis karena tidak memiliki aturan dan melupakan fungsi asli dari lingkungan itu sendiri seperti di wilayah resapan air dan D aerah Aliran Sungai (DAS) yang mengakibatkan banjir, penurunan permukaan air sungai yang dapat mengganggu jalur transportasi sungai (Maharyudi, 2006). Fungsi lingkungan di daerah perbatasan justru sangat penting karena tingkat varietas tumbuhan dan hewan yang beragam (Tahmrin, 2009).

Pengembangan perkebunan kelapa sawit di wilayah perbatasan Indonesia-M alaysia memiliki potensi konflik antarnegara. Ini terjadi karena Indonesia dan Malaysia mendominasi produksi dan perdagangan minyak sawit dunia. Malaysia meningkatkan penggunaan lahan di wilayah Indonesia untuk memperluas ekspansi mereka, di lain pihak, M alaysiajuga tergantung pada tenaga kerja dari Indonesia (Tagliacozzo, 2001; O bidzinski, 2006).

Konflik sawit yang memiliki implikasi dalam masalah lingkungan antarnegara juga berpotensi mengancam kedaulatan pihak berkonflik. Banyak ahli yang menyatakan bahwa tekanan lingkungan yang disebabkan oleh manusia dapat secara serius memengaruhi kedaulatan nasional. Kelangkaan lingkungan telah menyebabkan banyak sekali masalah sosial yang terakumulasi, seperti perpindahan penduduk, penurunan perekonomian, dan pelemahan negara. Keseluruhan hal tersebut dapat memunculkan kekacauan subnasional. Tingkat pertumbuhan konflik pun akan meningkat seiring dengan memburuknyakelangkaan (H omer-Dixon, 1991).

Kekacauan subnasional ini akan sama parahnya dengan perang-perang sumber daya antarnegara, dan juga akan mendapatkan perhatian khusus dari negara-negara maju maupun berkembang. Negara-negara dengan tekanan seperti ini tentu akan mempertimbangkan kembali tentang status dan kedaulatan yang dimilikinya (Homer-Dixon, 1991).

\section{PENGELOLAAN KONFLIK SECARA BERKELANJ UTAN}

Pembangunan berkelanjutan menurut Sumarwoto (2006) adalah ketergantungan sosial ekonomi terhadap ekologi namun tidak menimbulkan efek negatif bagi sosial masyarakat maupun ekologi itu sendiri. O leh karena itu, dibutuhkan sebuah sistem yang menyangkut kebijakan, perencanaan, dan proses pembelajaran sosial secara terpadu. Pola pembangunan yang hanya menekankan pada pertumbuhan ekonomi cenderung mengarah pada pemanfaatan sumber daya alam dan lingkungan yang kurang terkendali untuk keuntungan ekonomis semata. Karena itu kesadaran global yang diwujudkan melalui kesepakatan internasional melalui deklarasi Johannesburg pada tahun 2002 menekankan secara spesifik perlunya integrasi tiga pilar pembangunan yaitu aspek sosial, ekonomi, dan lingkungan.

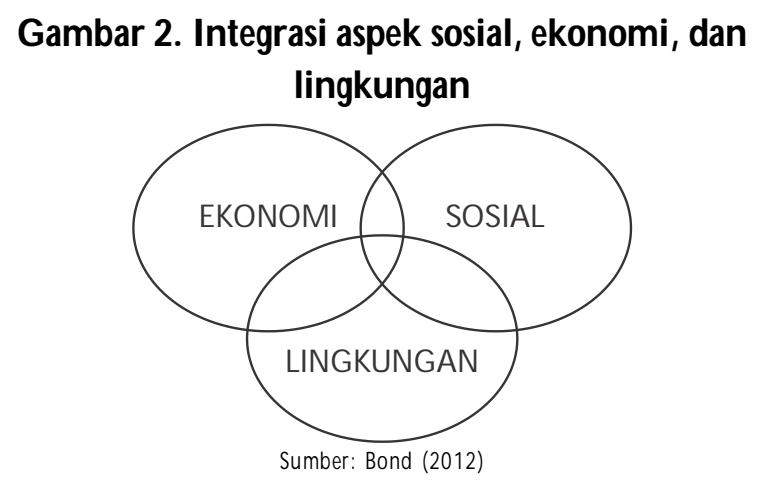

Kelahiran konsep pembangunan berkelanjutan memiliki dimensi bagaimana masa depan yang berkelanjutan disiapkan secara dini dan terpadu. Pembangunan berkelanjutan adalah upaya sadar dan terencana, guna 
menjamin bagaimana masa depan peradaban dapat berlangsung. A sumsi selamaini, integrasi ekologi, ekonomi, dan sosial merupakan irisan yang saling bersinggungan. K arena itu berkelanjutan berarti kesepakatan secara multidimensional guna mencapai kualitas kehidupan yang lebih baik (Bond, 2012; Maharyudi, 2006). Dengan demikian, pembangunan berkelanjutan diartikan bahwa secara ekonomis bernilai guna, secara ekologis terjamin, dan secara sosial berlangsung sinergis (M ukhlis, 2009).

\section{Tabel 1. H ubungan keberlanjutan ekologis, ekonomi, dan sosial}

\begin{tabular}{llll}
\hline DIMENSI & EKONOMI & SOSIAL & LINGKUNGAN \\
\hline Ekonomi & Equitable growth & Ekonomi input & Ekonomi input \\
& & Sosial & sosial \\
Sosial & Sosial input ekonomi & Berantas & Sosial input \\
& & kemiskinan & lingkungan \\
Lingkungan & \multirow{2}{*}{ Lingkungan input sosial } & Lingkungan & Lestarikan \\
& & input sosial & ekosistem \\
\hline
\end{tabular}

Sumber: Salim (2004)

$\mathrm{H}$ al ini diperkuat dengan fakta bahwa saat ini hanya segelintir ilmuan yang menolak klaim bahwa penggunaan yang berlebihan atas sumber daya alam, polusi yang terusmenerus, dan kerusakan pada permukaan alam meningkatkan ancaman terhadap kehidupan di bumi (Sherad, 2006).

D alam pengelolaan sumber daya alam, terdapat istilah 'hak properti' sebagai bagian dari sistem legal. H ak-hak ini memperbolehkan pemilik properti atas penggunaan sebagian sumber daya yang dimiliki, misalnya hak untuk menggunakan, memiliki, mentransfer, dan meraih keuntungan. Tidak dapat dipungkiri bahwa sebagian dari pemilik hak ini berpotensi mengancam keselamatan umat manusia. Terutamajika hak atas objek properti yang dimiliki adalah sumber daya alam yang merupakan komponen penting dalam ekosistem alam (Smith et al., 1998).

Faktanya, kepemilikan hak properti tersebut telah menimbulkan masalah besar dalam peradaban dewasa ini. Namun mereka yang memiliki hak ini tidak dapat disalahkan begitu saja, karena di sisi lain mereka turut meningkatkan kualitas hidup banyak orang, terutama mereka yang menggunakan dan menikmati properti tersebut. D engan begitu, penyelidikan untuk melindungi privilese inilah satu-satunya jalan yang dapat dipilih untuk melawan para perusak lingkungan. $\mathrm{H}$ ak atas properti cenderung berselisih dengan kewajiban untuk melindungi lingkungan. M eskipun demikian, pada dasarnya, hak atas beberapa sumber daya lingkungan lebih mengarah kepada hak 'melayani' daripada hak yang 'sebebas-bebasnya.' Jadi, hak ini dapat diistilahkan menjadi 'hak menggunakan dengan secukupnya,' dan bukan 'hak menggunakan sebebas-bebasnya' (Sherad, 2006).

Sherad (2006) menyatakan bahwa hak atas properti secara konsep tidak berselisih dengan kewajiban untuk melindungi lingkungan. Selain itu, hak atas properti juga tidak memperbolehkan penggunaan yang menyebabkan terjadinya kerusakan lingkungan ataupun menimbulkan kualitas lingkungan yang di bawah standar. Dengan demikian, dapat dipahami bahwa hak atas properti bukan merupakan sebuah kesempatan untuk melakukan eksploitasi berlebihan terhadap sumber daya, melainkan menggunakannya untuk memenuhi kebutuhan orang banyak, dengan tetap memperhatikan kewajiban terhadap keberlangsungan lingkungan (Sherad, 2006; Sambol, 2010).

H omer-Dixon (1991) menyebutkan kelangkaan sumber daya alam dan daya dukung yang kurang akan membawa dampak konflik perebutan atas sumber daya alam tersebut. Kelemahan dari analisis Homer-Dixon adalah tidak membahas kekurangan dari struktur dan aturan yang ada dalam penyelesaian konflik serta kurangnya pemahaman terhadap budaya pada pihak yang bertikai (Timura, 2001).

\section{PARADIGMA PENYELESAIAN KONFLIK LINGKUNGAN}

Berdasarkan penelitian Douglass (2009), terdapat faktor-faktor yang menentukan saat-saat awal serta durasi dari konflik yang melibatkan sumber daya alam. Faktorfaktor ini diambil dari beberapa penelitian kuantitatif untuk menelusuri peranan sumber daya alam terhadap perang sipil. Penelitiannya menyimpulkan bahwa faktorfaktor paling penting yang memen garuhi saat awal konflik sumber daya internal adalah: (1) warisan sisa-sisa kolonial dan perang dingin; (2) perluasan terhadap kontrol pengambilan sumber daya; (3) kekuatan militer dari negara; (4) tingkat intervensi pihak luar pada konflik; dan (5) sumber-sumber yang asimetrik terhadap satu kasus pemerintah versus pemberontak. 
D ouglass (2009) menawarkan pendekatan baru dalam memahami peranan sumber daya alam terhadap sebuah konflik. Saat ini, sebagian besar ilmuwan terlalu berlebihan dalam memandang peranan konflik sumber daya alam. $N$ amun D ouglass (2009) berpendapat bahwa harus dapat dibedakan antara konflik yang disebabkan oleh sumber daya alam dengan konflik yang memang disebabkan oleh isu politik.

D alam konflik sumber daya alam terbarukan, H omerDixon (1991) mengatakan bahwa perebutan sumber daya alam terbarukan muncul karena krisis atau kelangkaan sumber daya terbarukan meningkat tajam. Sehingga di wilayah perbatasan, area yang awalnya diperuntukkan sebagai wilayah konservasi berubah menjadi wilayah produksi. Kondisi ini menyebabkan pembukaan lahan terus meningkat dan mengurangi luasan hutan-hutan dan spesies-spesies yang ada di dalamnya. Proses konflik sumber daya alam akibat usaha mengatasi kelangkaan menyebabkan degradasi kualitas lingkungan sehingga menimbulkan krisis lingkungan secara berkepanjangan yang dapat dalam bentuk konflik komunal atau bahkan internasional. Selain itu, aspek teritorial secara implisit maupun eksplisit memiliki hubungan dengan konflik sumber daya secara luas melalui asumsi bahwa nilai sumber daya adalah hakiki.

Di satu pihak, kelangkaan sumber daya dianggap sebagai pemicu konflik. Sementara itu, di sisi lain kelimpahan sumber daya dianggap sebagai faktor yang cukup berperan dalam kemunculan konflik (O 'Lear, 2005). M atthews et al. (2002) pernah melakukan evaluasi dan menyimpulkan bahwa dengan mengubah fungsi batas politik atau lokasi yang terkena dampak dari konflik akan secara perlahan mengurangi konflik itu sendiri. Peran pemerintah daerah dalam pengelolaan konflik menjadi penting karena definisi kepentingan yang berbeda dalam setiap tingkatan organisasi pemerintah terkait pengelolaan sumber daya alam. Dalam konteks kontrak sosial, negara merupakan payung individu-individu terikat dalam aturan hukum yang berlaku. N egara-negara berkembang mengatasi kelangkaan sumber daya alam dengan pola yang berbeda, namun biasanya terlihat bagaimana pemerintah tidak menaruh perhatian terhadap kekayaan kearifan lokal serta budaya masyarakat pengelola sumber daya alam yang seharusnya menjadi tonggak penopang eksistensi dan identitas suatu negara. Pemerintah juga tidak memberi perhatian teliti bagaimana perpindahan penduduk dalam skala besar ke suatu daerah lain akan memicu konflik identitas yang berkepanjangan.

Dari sudut pandang pendekatan ekologi politik, peran negara dengan aparatur pemerintahan di dalamnya menentukan bagaimana bentuk dan dinamika konflik, sehingga negara dituntut bukan hanya sebagai fasilitator dan juri (netral) tetapi juga aktor. Peran negara yang aktif membentuk kesamaan dalam proses pengambilan dan pelaksanaan keputusan ini menjadi penting karena ada perbedaan kepentingan antaraktor negara terkait pengel olaan sumber daya alam terbarukan; sehingga sesuai dengan pendekatan ekologi politik. Yang menjadi masalah adalah tingkat perbedaan kepentingan yang terjadi justru mengeskalasi konflik itu sendiri.

Dalam hal ini, posisi negara, masyarakat, dan swasta saling bersinggungan. M eskipun masyarakat sekitar secara turun-temurun telah memanfaatkan lingkungan, namun hal ini sekaligus dipengaruhi oleh kepentingan pasar yang lebih luas. Ekspansi pasar dalam pengelolaan lingkungan dilakukan ketika konsep investasi mulai dikenal. Pasar yang melalui bentuk perdagangan dan investasi pemodal didukung oleh kebijakan pemerintah.

\section{Gambar 3. H ubungan triangulasi negara, pasar, dan masyarakat}

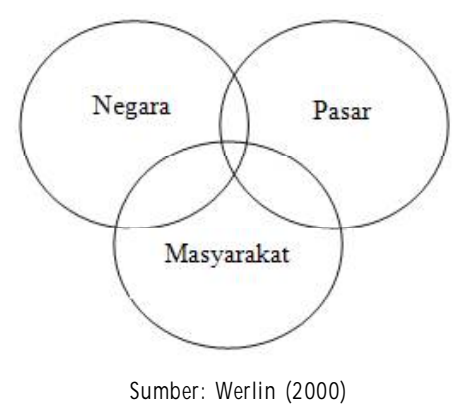

Werlin (2000) mengatakan, sewaktu penguasaan militer Indonesia, bentuk penguasaan militer sangat sedikit menaruh perhatian pada laju perusakan lingkungan dalam bentuk eksploitasi sumber daya. Kurangnya transparansi pemerintah akan aturan-aturan yang dibuat, mengakibatkan berbagai pelanggaran. Demokrasi lunak serta 
keterbukaan dalam informasi dan pemberian hak memilih untuk rakyat nampaknya menjadi solusi yang lebih tepat dibandingkan dengan rezim diktator, sehingga ada kontrol yang jelas terhadap aktor, tindakan, dan tujuan dalam mengatasi masalah pengel olaan lingkungan (Werlin, 2000).

Pemerintah sebagai pemegangtampuk utamakebijakan politik dalam pemanfaatan dan pelestarian lingkungan bertanggung jawab penuh atas hal tersebut. A kan tetapi, fakta yang ada adalah mencuatnya penindasan rakyat dan keterpurukan kualitas lingkungan. Pemerintah hanya menyelenggarakan aturan tapi pada akhirnya menghadapi resistansi undang-undang terhadap hak lokal (local rights). Resistansi ini juga akan berlanjut menjadi sebuah sumbangan bagi ketidakstabilan kontrol terhadap teritori (Peluso, 1993). A nalisis Peluso (1993) dalam pola pengelolaan sumber daya alam (berupa hasil hutan) mengatakan bahwa manajemen sumber daya alam di masa depan harus secara jelas melibatkan hak pembagian sumber daya alam dan tanggung jawab di dalamnya.

Dunlap dan Catton (1979) dalam G reen (2002) menyebutkan bahwa lingkungan alam merupakan faktor menonjol dalam perkembangan sosial. A kan tetapi, ada batas untuk bertumbuh dan manusia tidak dapat menggantungkan diri pada adaptasi pasar untuk mengatasi batas tersebut. Permasalahan yang timbul sekarang adalah bagaimana mengatasi konflik antara pemilik sumber daya dengan para pemegang kekuasaan dan pemilik modal, pendekatan seperti ini mengurai disparitas antara kaum dengan privilese dan yang tidak ( $G$ reen, 2002). Dari sinilah permasalahan sosial berakar. Maka perlu adanya suatu kerangka hubungan antara ekologi, sosial, dan ekonomi untuk mengatasi kelangkaan dan konflik sumber daya yang ada sehingga tidak sampai menimbulkan konflik global (G reen, 2002).

\section{KESIMPULAN}

Peran negara, masyarakat, dan pasar dalam pengelolaan sumber daya al am terbarukan merupakan model triangulasi yang saling terkait. Relasi ini sangat dinamis karena jika negara berperan dominan, maka negara mampu menekan gerak korporasi dan komunitas sehingga terjadi relasi otoriter. Jika korporasi lebih kuat, makakorporasi mampu melakukan kontrol terhadap pemerintah dan masyarakat sehingga konsekuensinya adalah eksploitasi sumber daya alam. Jika kondisi komunitas san gat kuat, maka komunitas memiliki kuasa lebih besar terhadap pemerintah dan masyarakat sehingga muncul anarkisme, atau masyarakat tanpa negara. Masing-masing relasi ini memiliki kepentingan, daya juang, dan terjebak pada perilaku merusak. Pendekatan ekologi politik memahami bahwa keseimbangan yang hierarkis dibutuhkan dari masing-masing peran. N egara memayungi pasar dan masyarakat, demikian juga masyarakat dan pasar sebagai bagian dari sistem yang diatur negara, sehingga sesuai dengan pendekatan ekologi politik, di mana masalah tingkat perbedaan kepentingan yang terjadi justru meningkatkan konflik itu sendiri. M anajemen sumber daya alam di masa depan harus secara jelas melibatkan hak pembagian sumber daya alam dan tanggung jawab pengelolaan di dalamnya.

\section{UCAPAN TERIMA KASIH}

Tulisan ini merupakan bagian dari disertasi di IImu Lingkungan U niversitas Indonesia. Penulis mengucapkan terima kasih atas dukungan dan bimbingan dari Prof. Dr. Budi Soesilo Soepandji dari Fakultas Teknik U niversitas Indonesia, Francisia Seda Ph.D. dari D epartemen Sosiologi U niversitas Indonesia dan D r. O etami D ewi dari Kementerian Sosial Republik Indonesia. Penulis mengucapkan terima kasih juga kepada Lembaga Ketahanan $\mathrm{N}$ asional (Lemhannas) yang mendukung diseminasi riset di Jepang, dan D ewan Perwakilan Daerah yang menugaskan pendampingan di Kalimantan Barat dan Serawak-M alaysia.

\section{REFERENSI}

Bond, A., M orrison-Saunders, A., \& Pope, J. (2012). Sustainability Assessment: the State of the Art. Impact Assessment and Project Appraisal, 30(1), pp.53-62.

Cockburn, A. \& Ridgeway, J. (1979). Political Ecology. New York: Times Book.

Douglass, K. L. (2009). Bling without Blood? The Role of Natural Resources in Civil War II. Disertasi The University of Tennessee.

Eilenberg, M. \& Wadley, R. L. (2009). Borderland Livelihood Strategies: The Socio economic Significance of Ethnicity in Cross border Labour Migration, West Kalimantan, Indonesia. Asia Pacific Viewpoint, 50(1), pp.58-73.

Erman, E. (2018). Di balik Keberlanjutan Sawit: Aktor, Aliansi dalam Ekonomi Politik Sertifikasi Uni Eropa. Masyarakat Indonesia, 43(1).

Fisher, J. D. (2010). The Ecological Correlates of Armed Conflict: a Geospatial and Spatial-Statistical Appraoch to Conflict 
Modeling. UMI 3406546.

Forsyth, T. (2003). Critical Political Ecology: the Politics of Environmental Science. London: Routledge.

Gleditsch, N. P. (1998). Armed Conflict and the Environment: a Critique of the Literature. Journal of Peace Research, 35(3).

Green, B. E. (2002). Sharing Water: a Human Ecological Analysis of the Causes of Conflict and Cooperation Between Nations over Freshwater Resources. Disertasi The Ohio State University.

Handadhari, T. (2010). TKI dan Sawit Malaysia. Kompas 9 Oktober 2010.

Hardin, G. (1968). The Tragedy of the Commons. 162(1968):12431248.

Hauge, W. \& Ellingsen, T. (1998). Beyond Environmental Scarcity: Causal Pathways to Conflict. Journal of Peace Research, 35(3).

Hempel, L. C. (1996). Environmental Governance: The Global Challenge. Island Press.

Homer-Dixon, T. F. (1991). On the Threshold: Environmental Changes as Causes of Acute Conflict. International Security, 16(2).

Kanyamibwa, S. (1998). Impact of War on Conservation: Rwandan Environment and Wildlife in Agony. Biodiversity \& Conservation, 7(11), pp.1399-1406.

Maharyudi, P. (2006). Model Pengelolaan Sumber Daya Hutan Berkelanjutan di Wilayah Perbatasan Kalimantan Barat. Disertasi di Sekolah Pasca Sarjana IPB.

Mandel, R. (1980). Transnational Resource Conflict: The Politics of Whaling. International Studies Quarterly, 24(1).

Martin, W. (2003). Developing Countries Changing Participation in World Trade. The World Bank Research Observer, 18(2), pp.187-203.

Matthew, R. A. (2002). In Defense of Environment and Security Research. Environmental Change and Security Project Report, 8(Summer), pp.109-24.

McNeill, J. R. (2001). Something New Under the Sun: an Environmental History of the Twentieth-Century World (The Global Century Series). WW Norton \& Company.

Mukhlis, I. (2009). Eksternalitas, Pertumbuhan Ekonomi dan Pembangunan Berkelanjutan dalam Perspektif Teoritis. Jurnal Ekonomi Bisnis, 2009(14).

M winyihali, R. \& Hart, T. (2001). Armed Conflict and Biodiversity in Sub-Saharan Africa: the Case of the Democratic Republic of Congo (DRC).

Nesadurai, H. E. (2018). Transnational Private Regulation and the Global Governance of Palm Oil Sustainability: from Roundtable on Sustainable Palm Oil Certification to the Palm Oil Innovation Group/No-Deforestation Standard. Chapters, pp.187-198.

Ngadi, N., \& Noveria, M. (2018). Sustainabilitas Perkebunan Kelapa Sawit di Indonesia dan Prospek Pengembangan di Kawasan Perbatasan. Masyarakat Indonesia, 43(1).

O'Lear, S. (2005). Resource Concerns for Territorial Conflict. GeoJournal, 64(4), p.297.

Obidzinski, K. (2006). Timber Smuggling in Indonesia: Critical or Overstated Problem?: Forest Governance Lessons from Kalimantan. CIFOR.

Peet, R. \& Watts, M. (1996). Liberation Ecologies: Environment, Development, Social Movements. London: Routledge.
Peluso, N. L. (1993). Coercing Conservation? The Politics of State Resource Control. Global Environmental Change, 3 (2): pp.199217.

Potter, L. (2008, July). Dayak Resistance to Oil Palm Plantations in West Kalimantan, Indonesia. Di dalam: $17^{\text {th }}$ Biennial Conference of the Asian Studies Association of Australia [Internet] (pp. 13).

Sambol, A. R. (2010). Regional Perspectives of the Republican River Transboundary Conflict. UMI 1474988.

Satria, A. (2006, 13 April). Krisis Ekologi Politik. Tempo.

Sheard, M. (2006). Property Rights in Environmental Resources. The University of Auckland.

Smith, J. W. \& Sauer-Thompson, G. (1998). Civilization's Wake: Ecology, Economics and the Roots of Environmental Destruction and Neglect, Population and Environment, 19(6).

Soemarwoto, O. (2006). Pembangunan Berkelanjutan: Antara Konsep dan Realitas. Proceeding Stadium Ganeral pada Ulang Tahun ke-80 di Universitas Padjadjaran. Bandung, 20.

Tagliacozzo, E. (2001). Border Permeability and the State in Southeast Asia: Contraband and Regional Security. Contemporary Southeast Asia, pp.254-274.

Thamrin. (2009). Model Pengembangan Kawasan Agropolitan secara Berkelanjutan di Wilayah Perbatasan Kalimantan BaratMalaysia; Studi Kasus W ilayah Perbatasan Kabupaten Bengkayang dan Serawak. Disertasi di Sekolah Pasca Sarjana IPB.

Timura, C. T. (2001). Environmental Conflict and the Social Life of Environmental Security Discourse. Anthropological Quarterly, 74(3).

Weinstein, J. M. (2005). Resources and the Information Problem in Rebel Recruitment. Journal of Conflict Resolution, 49(4), pp.598-624.

Werlin, H. H. (2000). Linking Public Administration to Comparative Politics. PS: Political Science \& Politics, 33(3), pp.581-588. 